\title{
Rearing characteristics of fattening Hanwoo steers managed in different stocking densities
}

\author{
Jae Jung $\mathrm{Ha}^{1, \mathrm{a}}$, Ka Young Yang ${ }^{2, \mathrm{a}}$, Dong Yep $\mathrm{Oh}^{1}$, Jun Koo Yi ${ }^{1}$, and Jong Joo $\mathrm{Kim}^{3, *}$
}

* Corresponding Author: Jong Joo Kim Tel: +82-53-810-3027, Fax: +82-53-801-3027,

E-mail: kimjj@ynu.ac.kr

1 Gyeongbuk Livestock Research Institute, Yeongju 36052, Korea

${ }^{2}$ Animal Environment Division National Institute of Animal Science, Wanju 55365, Korea

${ }^{3}$ Department of Biotechnology, Yeungnam University, Gyeongsan 38541, Korea

a These authors contributed equally to this work.

ORCID

Jae Jung $\mathrm{Ha}$

https://orcid.org/0000-0001-6785-6346 Jong Joo Kim

https://orcid.org/0000-0001-9687-0075

Submitted Jun 13, 2017; Revised Jun 28, 2017; Accepted Aug 14, 2017
Objective: This study was conducted to analyze the effects of stocking density on growth and carcass quality, and behavior of Hanwoo cattle to conform with global trends, targeting animal welfare production through the practice of environmentally friendly condition.

Methods: Thirty six steers were randomly assigned to three treatment groups (C: 5 heads, T1: 4 heads, T2: 3 heads) and reared in separate pens with a constant stocking density of $50 \mathrm{~m}^{2}$ (C: $10 \mathrm{~m}^{2} /$ head, T1: $12.5 \mathrm{~m}^{2} /$ head, T2: $16.67 \mathrm{~m}^{2} /$ head) per group from 12 to 30 month of age. Growth performance, behavior and carcass quality traits of each steer were recorded and compared between the treatment groups.

Results: In general, the average daily gain during the fattening period was lower in group T2 than in $\mathrm{T} 1$ and the control groups. However, carcass weight and dressing percentage was lower in the control group than in T1 or T2 groups $(\mathrm{p}<0.05)$. Also, marbling score at 30 months of age was the lowest in the control group ( $<<0.05)$, while the three heads group (T2) had the greatest longissimus muscle area and marbling score $(\mathrm{p}<0.05)$. The behavior of walking time was the greatest in T2 group, while self-grooming and fighting occurred with the most frequency in the control group $(\mathrm{p}<0.05)$.

Conclusion: Our results show that the steers in more spacious stocking density had better carcass quality and wellbeing related behaviors, indicating that a lower density has a positive effect on raising management and carcass quality. Thus it is a need to install appropriate pens fitted to welfare-oriented management practices from growing to fattening period in Hanwoo cattle.

Keywords: Growth Performance; Behavior; Carcass Trait; Stocking Density; Hanwoo

\section{INTRODUCTION}

Korean beef consumers prefer Hanwoo beef with high quality to imported beef [1], and many studies have been conducted to improve meat productivity and quality of Hanwoo. It is also important to develop strategies to export Hanwoo meat. Although various factors influence the production of Hanwoo meat [2], the rearing space within the barn, in which an individual is raised from birth until 24 hours prior to shipment, vegetable diet space and stocking density including resting space could be important factors influencing meat quality [3].

Several inhibiting factors under overcrowded rearing conditions could be occurred such as the indoor temperature, changes in humidity within the barn, aggravation of air, depreciation of hygienic state due to excrement, or increased disease contraction ratio along with decreased growth rate owing to the rapid disintegration of nutrients within body, because of social stresses caused by small space between animals [4]. However, the negative factors can be avoided by conducting environmentally friendly rearing, which would then improve meat quality $[5,6]$.

Recently, it is reported that barn facilities have adopted natural air circulation by elevating 
roof height, or installed automatic feeders, or hen and cow brushes to better manage livestock $[7,8]$. However, studies on behavior relevant to rearing space have not focused on proper animal stocking density in Hanwoo [9].

Therefore, this study aimed to investigate the effects of different stocking densities on meat production and behavior characteristics in Hanwoo, so as to provide a basis on establishment of management practices to meet the condition of animal welfare and good meat quality.

\section{MATERIALS AND METHODS}

\section{Animals and experiment design}

Thirty-six Hanwoo steers were randomly chosen in Gyeongbuk Livestock Research Institute from May, 2014 to November, 2015. Preliminary experiments were carried out for three weeks, such that the individuals were grouped by considering average weight. The average yearling weight of the individuals was $291.4 \pm 12.2 \mathrm{~kg}$ at 12 month of age. The steers were raised in the same rearing area of $50 \mathrm{~m}^{2}$ per pen, whereas the stocking density varied (Figure 1). In the pen for the control group (C), a set of five steers of 12 to 30 months of age was assigned, so as to allow $10 \mathrm{~m}^{2}$ per head of rearing space. For treatment 1 (T1) and treatment 2 (T2) groups, four and three steers were assigned in a pen, so as to give $12.6 \mathrm{~m}^{2}$ and $16.7 \mathrm{~m}^{2} /$ head rearing space, respectively. Each steer was randomly assigned to each treatment, and three replicates for each treatment were applied, totaling 36 samples $(3 \times 5[\mathrm{C}]+3 \times 4[\mathrm{~T} 1]+3 \times 3[\mathrm{~T} 2])$.

\section{Animal management}

The nutrient composition of feedstuffs is presented in Table 1 [10]. All animals were given the same diets, while forage was restricted to consumption of rice straw. The amount of feedstuffs was changed at three month intervals that were based on the mean body weight.

The fattening stage was divided into two phases: phase I (12 to 21 months of age) and phase II (22 to 30 months of age), and the average amount of concentrate feeding for a day was 5.5 to $10.5 \mathrm{~kg}$ per steer, which was approximately equal to $1.6 \%$ to $1.8 \%$ of body weight (Table 2). During the fattening period, rice straw diets were provided ad libitum, twice a day at $8 \mathrm{am}$

Table 1. Composition of nutrients in the experimental feedstuffs for Hanwoo steers

\begin{tabular}{lccc}
\hline \multirow{2}{*}{ Nutrients (\%) } & \multicolumn{2}{c}{ Concentrate } & Rice \\
\cline { 2 - 3 } & Early fattening & Late fattening & \\
\hline straw matter & 83.55 & 83.18 & 90.09 \\
Crude protein & 14.19 & 12.31 & 4.53 \\
Crude fat & 3.49 & 4.87 & 2.17 \\
Crude fiber & 4.57 & 4.25 & 27.66 \\
Crude ash & 4.85 & 5.90 & 14.31 \\
Calcium & 0.72 & 0.94 & 0.22 \\
Phosphorous & 0.42 & 0.35 & 0.12 \\
Total digestible nutrients & 72.43 & 73.75 & 37.13 \\
\hline
\end{tabular}

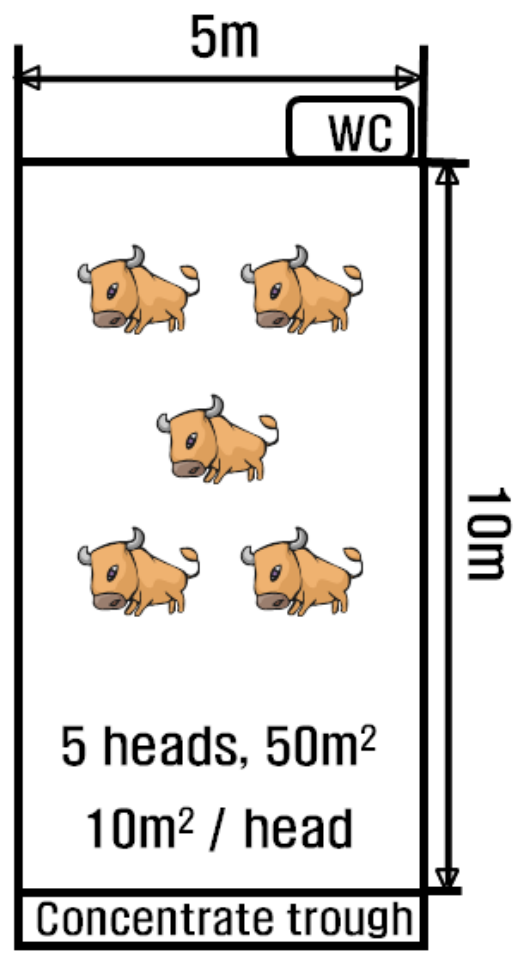

Control

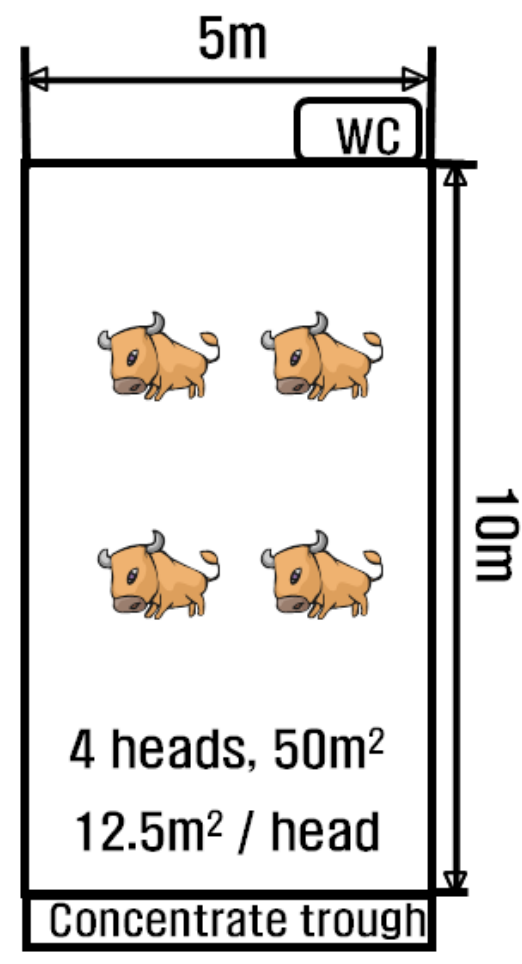

Treatment 1

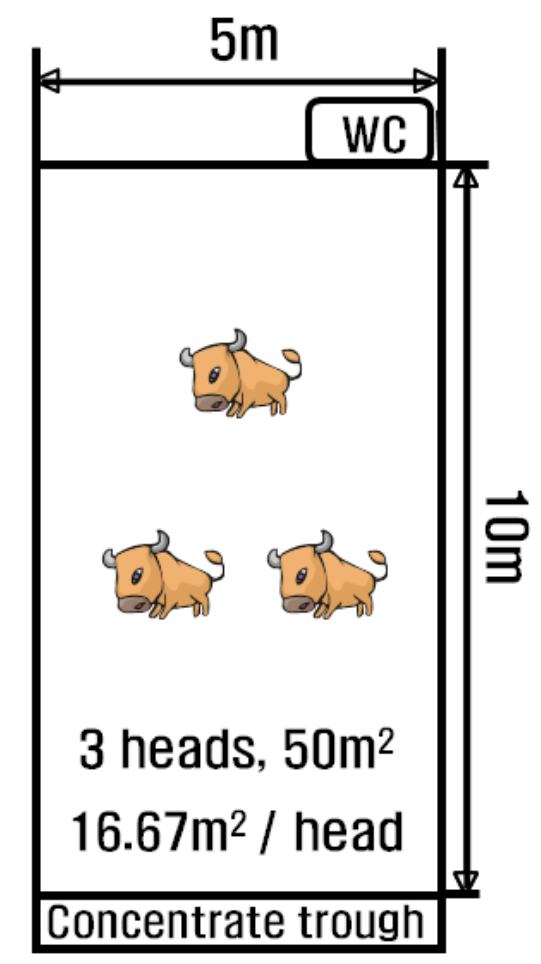

Treatment 2

Figure 1. Experimental design of different stoking densities. 
Table 2. The amounts of feed intake in the two main fattening phases

\begin{tabular}{lccc}
\hline \multirow{2}{*}{ Month } & & \multicolumn{2}{c}{ Feed intake $(\mathbf{k g} /$ head/d) } \\
\cline { 3 - 4 } & & Concentrate & Rice straw \\
\hline Phase I & 12 & 5.5 & 3.5 \\
(Early fattening) & 13 & 6 & 3.5 \\
& 14 & 6 & 3.5 \\
& 15 & 6.5 & 3 \\
& 16 & 7 & 3 \\
& 17 & 7 & 3 \\
& 18 & 7.5 & 2.5 \\
& 19 & 8 & 2.5 \\
Phase II & 20 & 8 & 2.5 \\
(Late fattening) & 21 & 8.5 & 2 \\
& 22 & 8.5 & 2 \\
& 23 & 9 & 2 \\
& 24 & 9 & 1.5 \\
& 25 & 9.5 & 1.5 \\
& 26 & 9.5 & 1.5 \\
& 27 & 10 & 1 \\
& 28 & 10 & 1 \\
& 29 & 10.5 & 1 \\
& 30 & 10 & 0.5 \\
\hline
\end{tabular}

and $5 \mathrm{pm}$, respectively. One water dish and mineral block trough was provided per group, allowing animals to be freely accessed to feed and water.

\section{Data collection}

The total amount of feed intake per steer was recorded by measuring the differences of feed weight provided each day and residual quantity at the end of the next morning (Table 3). Body weight of each steer was measured between 12 and 30 months of age in a three month interval, i.e. before morning feeding at the beginning of each quarter (Table 4). Average daily gain (ADG) between three month intervals was also calculated (Table 5). To evaluate carcass quality traits, a $2 \mathrm{MHz}$ real time ultrasound equipment was applied between the 13th rib and lumber vertebra (HS-2000; HONDA, Tokyo, Japan). The images reflecting ultrasound back fat thickness, longissimus muscle area, and marbling score were processed and analyzed using the Image-pro Express (Version 4.1, Media Cybernetics, Rockville, MD, USA) software. Also, all of the steers were slaughtered at a local municipal slaughterhouse at 30 months of age, and carcass quality traits were evaluated according to the Korean

Table 3. The average amounts of feed intake ( $\mathrm{kg} / \mathrm{head})$ in different stocking densities in Hanwoo steers

\begin{tabular}{lccc}
\hline \multirow{2}{*}{ Feeds } & \multicolumn{3}{c}{ Stocking density group } \\
\cline { 2 - 4 } & Control $^{1)}$ & Treatment 1 $^{2)}$ & Treatment 2 \\
\hline Total & $5,386 \pm 47$ & $5,403 \pm 47$ & $5,430 \pm 47$ \\
Concentrate & $4,193 \pm 21$ & $4,198 \pm 21$ & $4,212 \pm 21$ \\
Rice straw & $1,193 \pm 14$ & $1,205 \pm 14$ & $1,218 \pm 14$ \\
\hline
\end{tabular}

1) $10 \mathrm{~m}^{2} /$ head. ${ }^{2)} 12.5 \mathrm{~m}^{2} /$ head. ${ }^{3)} 16.7 \mathrm{~m}^{2} /$ head.
Table 4. Effects of different stocking density on body weight $(\mathrm{kg})$ in Hanwoo steers

\begin{tabular}{llll}
\hline \multirow{2}{*}{ Month } & \multicolumn{3}{c}{ Treatments } \\
\cline { 2 - 4 } & \multicolumn{1}{c}{ Control $^{\text {1) }}$} & Treatment 1 $^{2)}$ & Treatment 2 \\
\hline 12 & $283.8 \pm 16.7$ & $292.3 \pm 16.0$ & $298.3 \pm 16.2$ \\
15 & $351.6 \pm 13.8^{\mathrm{b}}$ & $362.8 \pm 11.5^{\text {ab }}$ & $370.7 \pm 10.7^{\mathrm{a}}$ \\
18 & $417.3 \pm 11.6^{\mathrm{ab}}$ & $412.1 \pm 12.3^{\mathrm{b}}$ & $438.4 \pm 10.6^{\mathrm{a}}$ \\
21 & $508.2 \pm 13.1^{\mathrm{b}}$ & $519.5 \pm 11.2^{\mathrm{ab}}$ & $525.3 \pm 12.4^{\mathrm{a}}$ \\
24 & $560.0 \pm 20.3$ & $575.0 \pm 16.8$ & $581.3 \pm 17.1$ \\
27 & $631.0 \pm 18.6$ & $639.7 \pm 14.0$ & $644.3 \pm 18.4$ \\
30 & $683.5 \pm 21.3$ & $680.6 \pm 27.0$ & $683.7 \pm 25.5$ \\
\hline
\end{tabular}

1) $10 \mathrm{~m}^{2} /$ head. ${ }^{2)} 12.5 \mathrm{~m}^{2} /$ head. ${ }^{3)} 16.7 \mathrm{~m}^{2} /$ head.

$a, b$ Means with different superscripts in the same row differ significantly $(p<0.05)$.

carcass grading standard [11].

Digital cameras (IR LED camera; Sony, Changwon, Korea) and video-recording devices (STLV-36D; Samsung, Korea) were utilized for precise monitoring of animal behaviors within each treatment group. Nine digital cameras were allocated in front of the feeding area of each pen at a height of approximately $3 \mathrm{~m}$. Animal behavior for a given quarter interval was analyzed by selecting a month and by recording on every weekend of the month. Behavior characteristics were classified as six categories, i.e. standing, lying down, walking, self-grooming, leaning, and fighting (Figure 2), and each individual was observed for 12 hours a day from 7 am to $7 \mathrm{pm}$. Behavioral time was analyzed by sampling at a two minute interval of the observation records, after which the best behavioral category was determined for each individual [12].

\section{Statistical analysis}

The mean value of the analyzed traits was calculated for each treatment group. Statistical analysis was conducted using the general linear model Procedure, Statistical Analysis System [13] by fitting a linear model with one main effect of different stocking density. Duncan multiple range tests were used to determine statistical significance between treatment means at 0.05 level.

Table 5. Effects of different stocking density on average daily gain $(\mathrm{kg} / \mathrm{d})$ in Hanwoo steers

\begin{tabular}{lccc}
\hline \multirow{2}{*}{ Month } & \multicolumn{3}{c}{ Treatments } \\
\cline { 2 - 4 } & Control $^{1)}$ & Treatment $1^{2)}$ & Treatment 2 ${ }^{3)}$ \\
\hline $12-15$ & $0.75 \pm 0.16$ & $0.78 \pm 0.03$ & $0.76 \pm 0.14$ \\
$15-18$ & $0.73 \pm 0.09^{\mathrm{a}}$ & $0.55 \pm 0.04^{\mathrm{b}}$ & $0.64 \pm 0.07^{\mathrm{ab}}$ \\
$18-21$ & $1.01 \pm 0.19^{\mathrm{ab}}$ & $1.19 \pm 0.06^{\mathrm{a}}$ & $0.96 \pm 0.09^{\mathrm{b}}$ \\
$12-21$ & $0.83 \pm 0.08$ & $0.84 \pm 0.09$ & $0.84 \pm 0.12$ \\
$21-24$ & $0.58 \pm 0.13$ & $0.62 \pm 0.04$ & $0.62 \pm 0.03$ \\
$24-27$ & $0.79 \pm 0.14$ & $0.72 \pm 0.10$ & $0.70 \pm 0.01$ \\
$27-30$ & $0.58 \pm 0.08$ & $0.46 \pm 0.21$ & $0.44 \pm 0.19$ \\
$21-30$ & $0.65 \pm 0.14$ & $0.60 \pm 0.12$ & $0.59 \pm 0.11$ \\
$12-30$ & $0.74 \pm 0.08$ & $0.72 \pm 0.07$ & $0.71 \pm 0.05$ \\
\hline 1) $10 \mathrm{~m}^{2} /$ head. $^{2)} 12.5 \mathrm{~m}^{2} /$ /head. $^{3)} 16.7 \mathrm{~m}^{2} /$ head. \\
a,b Means with different superscripts in the same row differ significantly $(\mathrm{p}<0.05)$.
\end{tabular}



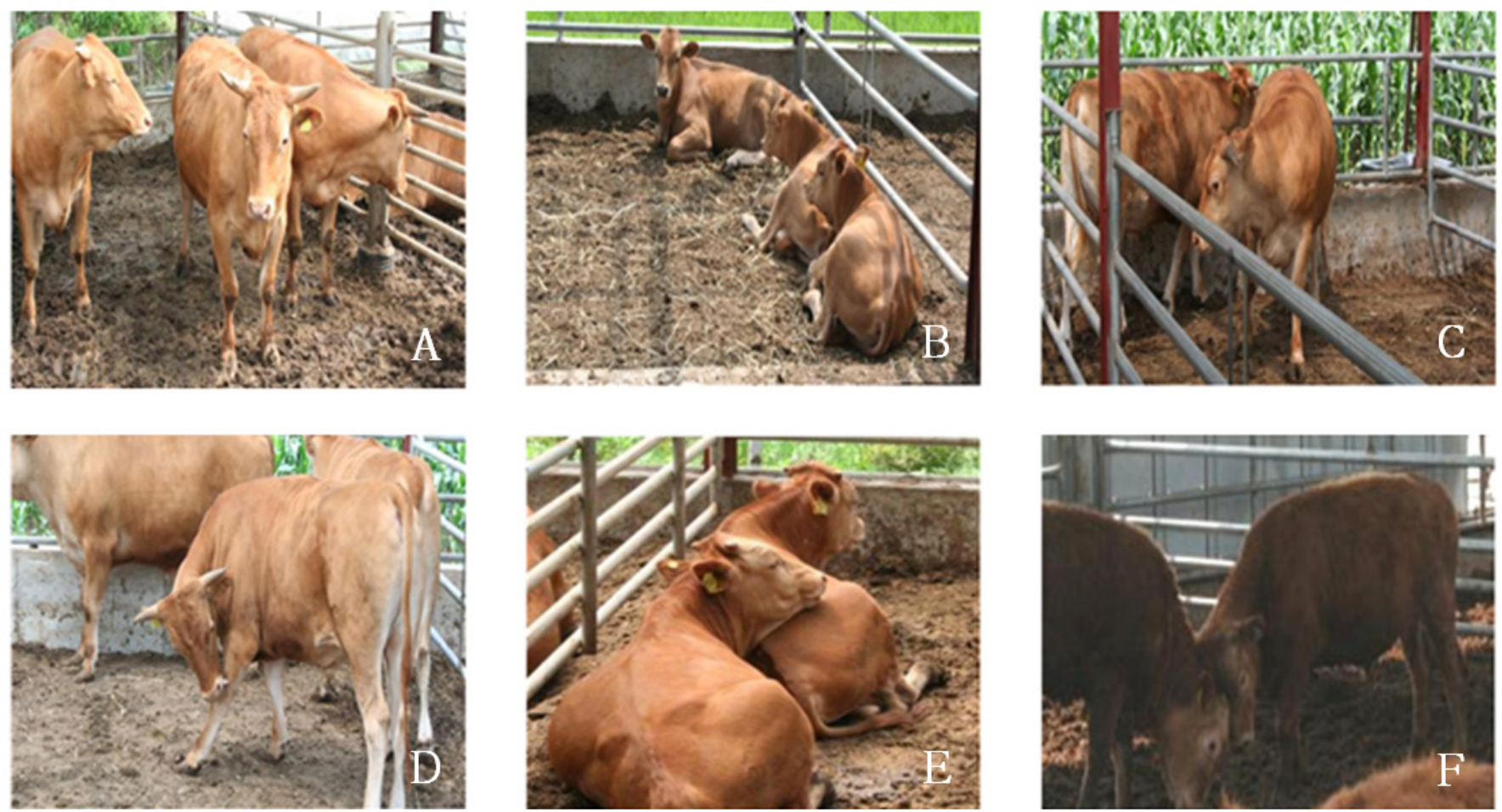

Figure 2. Classification of behavior characteristics. (A) Standing (ST), (B) Lying down (LD), (C) Walking (WA), (D) Self grooming (SG), (E) Leaning (LN), (F) Fighting (FT).

\section{RESULTS AND DISCUSSION}

\section{Growth performance}

Table 3 shows the average of total feed intake per steer. The amounts of feed intake were not significantly different between different space density groups ( $p>0.05)$. However, the steers in more spacious groups had marginally more feed intakes, which may be due to more appetite with increasing activity.

Generally T2 group had heavier body weights than the control and $\mathrm{T} 1$ groups during the early fattening period $(\mathrm{p}<0.05)$ (Table 4). This result supports the report of Boe and Faerevik [14], in which the welfare of livestock was closely related to productivity. Also, Rind and Phillips [15] reported that it was important to provide sufficient space to ensure welfare and productivity of cattle. However, there was no statistical significance of difference of body weight at 30 months of age between the three treatment groups in this study (Table 4). At 15 to 18 months of age, the control group had greater ADG than T1 group ( $\mathrm{p}<0.05$ ), but $\mathrm{T} 1$ group had higher $\mathrm{ADG}$ than the control and T2 groups at 18 to 21 months of age. This result corresponds to the report of Li et al [16], in which the animals reared with a large group size had significantly greater ADG in an early fattening period. This result reflects strong competition on eating in a large group. As fattening period is extended, the relative space becomes more limited for the steers in denser pens and thus activity of the steers would decrease correspondingly.

In the late fattening period (21 to 30 month), the steers in
T2 group, in general, had lowest ADG, followed by T1 and the control group, even if there was no statistical significance between the treatment groups (Table 5).

$\mathrm{Li}$ et al [16] reported that the animals reared in a spacious group had greater ADG in an early fattening period. However, our results in this study were not consistent with Li et al [16]. Further, the boy weight at 30 months of age was not significantly heavier in the T2 group (Table 4). This result might be partly due to the fact that the density space $\left(10 \mathrm{~m}^{2}\right.$ per steer) in the control group was larger than the average space ( 7 to 8 $\mathrm{m}^{2}$ per steer) in the Hanwoo farms, so that Hanwoo steers have been well adapted to low stocking density pens for the several decades. Also, the average live weight of steers in Hanwoo farms before slaughter was around $700 \mathrm{~kg}$, while our results showed around $680 \mathrm{~kg}$ in the control group, i.e. about $3 \%$ lower, which might be due to more motility of the steers in spacious stocking density than in Hanwoo farms.

Berg and Butterfield [17] reported that ADG was also affected by differences between individuals, nutritional level of feeds or other various environmental factors. Therefore, further investigation on the relationship between ADG and motility is needed.

\section{Carcass characteristics}

Table 6 shows ultrasound carcass quality traits at different growth stages and at slaughter. In general, T2 group had lower back fat thickness across all growth stages, except at slaughter, even though there was no statistical significance $(p>0.05)$. This 
Table 6. Effects of different stocking density on ultrasound and carcass quality traits of Hanwoo steers

\begin{tabular}{|c|c|c|c|c|}
\hline \multirow{2}{*}{ Items } & \multirow{2}{*}{ Months } & \multicolumn{3}{|c|}{ Treatments } \\
\hline & & Control $^{1)}$ & Treatment $1^{2)}$ & Treatment $2^{3)}$ \\
\hline \multirow[t]{6}{*}{ BFTU (mm) } & 12 & $1.50 \pm 0.93$ & $1.13 \pm 0.34$ & $1.21 \pm 0.59$ \\
\hline & 15 & $1.75 \pm 1.16$ & $1.25 \pm 0.45$ & $1.29 \pm 0.75$ \\
\hline & 18 & $2.63 \pm 1.69$ & $1.94 \pm 0.93$ & $2.33 \pm 1.27$ \\
\hline & 21 & $4.00 \pm 2.33$ & $3.56 \pm 1.15$ & $3.92 \pm 1.38$ \\
\hline & 24 & $4.75 \pm 2.60$ & $4.56 \pm 1.63$ & $4.71 \pm 1.82$ \\
\hline & 27 & $6.25 \pm 3.01$ & $6.25 \pm 2.27$ & $6.13 \pm 2.02$ \\
\hline BFTC (mm) & 30 & $9.63 \pm 3.02$ & $9.75 \pm 2.72$ & $10.26 \pm 2.47$ \\
\hline \multirow[t]{6}{*}{$\operatorname{LMAU}\left(\mathrm{cm}^{2}\right)$} & 12 & $42.86 \pm 3.61$ & $46.03 \pm 4.20$ & $45.79 \pm 3.86$ \\
\hline & 15 & $48.11 \pm 3.77$ & $49.92 \pm 3.59$ & $50.93 \pm 4.17$ \\
\hline & 18 & $60.16 \pm 3.58$ & $60.63 \pm 3.35$ & $62.56 \pm 3.40$ \\
\hline & 21 & $72.59 \pm 3.83$ & $71.90 \pm 3.54$ & $72.86 \pm 4.60$ \\
\hline & 24 & $77.56 \pm 2.68$ & $77.83 \pm 3.31$ & $78.09 \pm 4.39$ \\
\hline & 27 & $84.00 \pm 5.38$ & $85.72 \pm 4.69$ & $85.93 \pm 4.35$ \\
\hline $\operatorname{LMAC}\left(\mathrm{cm}^{2}\right)$ & 30 & $91.00 \pm 6.68$ & $92.81 \pm 6.80$ & $94.55 \pm 6.66$ \\
\hline \multirow[t]{6}{*}{ MSU } & 12 & $1.00 \pm 0.00$ & $1.00 \pm 0.00$ & $1.00 \pm 0.00$ \\
\hline & 15 & $1.00 \pm 0.00$ & $1.00 \pm 0.00$ & $1.00 \pm 0.00$ \\
\hline & 18 & $1.88 \pm 0.99$ & $2.06 \pm 0.85$ & $2.67 \pm 1.13$ \\
\hline & 21 & $2.63 \pm 1.06$ & $2.25 \pm 1.06$ & $2.96 \pm 1.40$ \\
\hline & 24 & $3.75 \pm 1.16$ & $4.00 \pm 1.26$ & $4.42 \pm 1.44$ \\
\hline & 27 & $5.00 \pm 1.98$ & $5.38 \pm 1.82$ & $6.13 \pm 1.58$ \\
\hline MSC & 30 & $5.25 \pm 1.57^{b}$ & $6.13 \pm 1.35^{\mathrm{a}}$ & $6.63 \pm 1.84^{a}$ \\
\hline
\end{tabular}

BFTU, ultrasound back fat thickness; BFTC, carcass back fat thickness; LMAU, ultrasound longissimus muscle area; LMAC, carcass longissimus muscle area; MSU, ultrasound marbling score; MSC, carcass marbling score.

1) $10 \mathrm{~m}^{2} /$ head. ${ }^{2)} 12.5 \mathrm{~m}^{2} /$ head. $^{3)} 16.7 \mathrm{~m}^{2} /$ head.

a,b Means with different superscripts in the same row differ significantly $(p<0.05)$.

may be partly due to greater motility environments in the T2 group compared to $\mathrm{T} 1$ and the control groups. Kang et al [18] reported a back fat thickness of $9.9 \mathrm{~mm}$ when the Hanwoo steers were slaughtered after rearing for 540 days under the similar management as in this study. They found that all treatment groups showed the greatest fat deposition after 27 months of age. Lee et al [19] reported that there was an increase in back fat thickness in response to an increased level of concentrated feeds during early and late fattening periods, and that back fat thickness increased with unlimited feeding concentrate at 24 months of age.

For the longissimus muscle area, T2 group was, in general, the greatest throughout the entire growth period and also at slaughter, i.e. $94.6 \mathrm{~cm}^{2}$, followed by T1 group $\left(92.8 \mathrm{~cm}^{2}\right)$, and the control group was lowest $\left(91.0 \mathrm{~cm}^{2}\right)$, even if statistical significance was limited between the groups, partly due to the small sample size (Table 6). This result was comparable to the report of KOSIS [20], in which the average longissimus muscle area of steers that were raised in Hanwoo farms and slaughtered was about $94.3 \mathrm{~cm}^{2}$, and are consistent with the report that an increase in motility leads to an increase in musculoskeletal system, thereby improving muscle quantity [21]. The longissimus muscle area in all treatment groups increased greatly from 18 to 21 months of age, when the ADG was the greatest. This result corresponds to Kim et al [22], who reported that increases in body weight led to increased longissimus muscle area.

The longissimus muscle area after slaughter ranged 91.0 to $94.6 \mathrm{~cm}^{2}$, which was greater than the result $\left(87.7 \mathrm{~cm}^{2}\right)$ of Kang et al [18], for which Hanwoo steers were fed with concentrated feed ad libitum during late fattening period. The difference of results between Kang et al [18] and this study may be partly due to different genetics of individuals and rearing factors.

The marbling was nearly absent (score, 1) for all steers before 18 months of age, after which marbling deposition occurred in all treatment groups (Table 6). After 18 months of age, T2 had the greatest marbling score across growth stages, and also at slaughter, while the control group had the smallest score $(\mathrm{p}<0.05)$. This result indicates that there is a relationship between fat deposition and motility of steers, i.e. the more spacious in a pen would cause greater motility of steers, such that more deposition of fat between muscles would occur. From the report of Hiroyuki et al [23], it can be inferred that beef cattle consumes large amounts of concentrated feed to convert surplus energy to fat accumulation. During the process of digestion and absorption metabolism for the excess energy of fat, a great deal of oxidative stress occurs in the cell, leading to an increase of active oxygen and nitric oxide and to inhibition of fat cell adiposity.

Table 7 shows the carcass weight and dressing percentage (ratio [\%] of carcass weight to final live weight before slaughter) for each stocking density. T1 (423 kg) and T2 (417 kg) groups had heavier carcass weights than the control groups $(398 \mathrm{~kg})(\mathrm{p}<0.05)$. Also, the dressing percentages for the T1 (62\%) and T2 (61\%) steers were significantly greater than the control group $(58 \%)(\mathrm{p}<0.05)$. This result supports the report that increasing motility during the fattening periods increased muscle amount, causing greater carcass rate [21].

\section{Behavior characteristics}

Table 8 shows the average time and frequency of the six behavior characteristics in different stocking densities. The time of standing behavior was the longest in the control group, but the shortest for $\mathrm{T} 2$ group, while for a resting behavior measure,

Table 7. Effects of different stocking density on carcass weight and dressing percentage in Hanwoo steers

\begin{tabular}{|c|c|c|c|}
\hline \multirow{2}{*}{ Items } & \multicolumn{3}{|c|}{ Treatments } \\
\hline & Control $^{1)}$ & Treatment $1^{2)}$ & Treatment $2^{3)}$ \\
\hline $\begin{array}{l}\text { Carcass weight } \\
\text { (kg/head) }\end{array}$ & $397.8 \pm 11.7^{b}$ & $423.4 \pm 16.9^{a}$ & $417.0 \pm 15.3^{\mathrm{a}}$ \\
\hline $\begin{array}{l}\text { Dressing percentage } \\
(\% / \text { head })\end{array}$ & $58.2 \pm 1.7^{b}$ & $62.2 \pm 2.6^{a}$ & $61.0 \pm 2.2^{\mathrm{a}}$ \\
\hline
\end{tabular}


Table 8. Effects of different stocking density on behavior characteristics in Hanwoo steers

\begin{tabular}{|c|c|c|c|}
\hline Items & Control $^{1)}$ & Treatment $1^{2)}$ & Treatment $2^{3)}$ \\
\hline \multicolumn{4}{|l|}{ Minute } \\
\hline Standing & $221.6 \pm 25.8$ & $209.5 \pm 19.4$ & $207.1 \pm 27.9$ \\
\hline Lying down & $119.8 \pm 27.8$ & $128.3 \pm 34.1$ & $130.6 \pm 20.3$ \\
\hline Walking & $14.5 \pm 7.7^{b}$ & $11.6 \pm 3.5^{b}$ & $34.8 \pm 17.4^{a}$ \\
\hline \multicolumn{4}{|l|}{ Count } \\
\hline Self grooming & $24.28 \pm 20.44^{a}$ & $10.30 \pm 8.12^{\mathrm{ab}}$ & $7.36 \pm 11.08^{b}$ \\
\hline Leaning & $5.41 \pm 1.86$ & $4.91 \pm 0.76$ & $4.27 \pm 1.13$ \\
\hline Fighting & $6.56 \pm 2.12^{\mathrm{a}}$ & $4.89 \pm 2.71^{\mathrm{ab}}$ & $3.24 \pm 2.66^{b}$ \\
\hline
\end{tabular}

lying-down, T2 group had the longest time, even if statistical significance was limited ( $>0.05)$. Houpt et al [24] reported that bulls spent 12 hours a day lying down, which means that steers spend much time in a lying-down position. Also, our results showed that the lying-down behavior was opposed to standing behavior. T2 had greater amount of walking behavior than the other two treatment groups $(\mathrm{p}<0.05)$. This result makes sense in that more space in the pen enabled the steers to allow more chance of motility. Instead, less time of walking would be caused by smaller space of the pen [25].

Self-grooming behavior may be caused by sanitary purposes or adaptation into the environment [26]. T2 group had the lowest frequency of self-grooming behavior, while the control group had the greatest frequency $(\mathrm{p}<0.05)$. Ishi [27] reported that narrow rearing spaces resulted in increased excretion storage areas, causing increased contamination of the fleece and skin, resulting in increased frequency of self-grooming behaviors.

The frequency of fighting was the greatest in the control group, while the lowest in $\mathrm{T} 2$ group $(\mathrm{p}<0.05)$. According to Kondo et al [28], high stocking density increased fighting behavior patterns such as intimidation, assault or fighting between group members. Our results also revealed more frequent fighting behavior in the control group (Table 8), which was supported by Zeeb et al [29], who reported reduced frequency of fighting behavior as stocking density decreased. Jensen et al [30] also reported that fighting behavior was affected by stocking density.

\section{IMPLICATIONS}

This study described the relationships between stocking density and growth and carcass quality traits as well as behavior characteristics in Hanwoo, and indicated positive effect of the spacious stocking density on carcass quality and behavior characteristics. Even if the samples to be used in this study were not large enough to give more definite evidence, our results point out the importance of spacious rearing conditions in improving meat quality traits of Hanwoo. Further study is needed to verify implementation of favorable pens to Hanwoo cattle to consider a positive effect on raising management and carcass quality, so as to fit to welfare-oriented management practices from growing to fattening period.

\section{CONFLICT OF INTEREST}

We certify that there is no conflict of interest with any financial organization regarding the material discussed in the manuscript.

\section{ACKNOWLEDGMENTS}

This work was conducted with the support of the "Cooperative Research Program for Agriculture Science \& Technology Development (Project title: Expansion of ex-situ conservation of national major seed stocks and animal genetic resources for livestock industry development in Gyeongsangbuk-do, Project No. PJ011639052018)" Rural Development Administration, Republic of Korea.

\section{REFERENCES}

1. Irie $\mathrm{M}$, Inno $\mathrm{Y}$, Ishizuka $\mathrm{Y}$, et al. Vitamins $\mathrm{A}$ and $\mathrm{E}$ in carcass fat from Japanese black and F1 cross cattle. Asian-Australas J Anim Sci 2006;19:1266-70.

2. Ha JJ, Yang KY, Yi JK, Oh DY. Effect of different rearing space area on growth performances, behavioral characteristics and blood parameters in Korean Native Cattle (Hanwoo). J Agric Life Sci 2016;50:83-94.

3. Morrison RS, Hemsworth PH, Cronin GM, Campbell RG. The effect of restricting pen space and feeder availability on the behaviour and growth performance of entire male growing pigs in deep-litter, large group housing system. Appl Anim Behav Sci 2001;83:163-76.

4. Dougherty WJ, Milham PJ, Havilah EJ, Lawrie RA. Phosphorus fertilizer and grazing management effects on phosphorus in runoff from dairy pastures. J Environ Qual 2008;37:417-28.

5. Ha JJ, Rhee YJ, Cho JH, et al. Behavioral characteristics on season and group size of Hanwoo steer. J Anim Environ Sci 2008;14:9-14.

6. Yang KY, Lee KH, Kim GW, et al. Studies on behavioral characteristics of Hanwoo steers according to pen and group size. Ann Anim Resour Sci 2015;26:128-34.

7. Kim JH, Yang KY, Ha JJ, Song YH. Effect of space allowance on the growth Performance, behavioral characteristics, and blood properties of Hanwoo. J Agric Life Sci 2015;49:113-21.

8. Ahn GC, Jang SS, Lee KY, et al. Characteristics of sawdust and cocopeat beddings, and their usefulness according to the fan and pen location for rearing Hanwoo cattle. Asian-Australas J Anim Sci 2016;29:444-54. 
9. Han JH, Jeon JH, Kim DJ, et al. Effects of space allowance on the social behavior of Korean native cattle (Bos taurus coreanae) steers. Korean J Vet Res 2005;45:245-50.

10.AOAC (Association of official analytical chemists). Official methods of analysis, 16th edn. animal feed: Association of official analytical chemists. Arlington, VA, USA: AOAC International; 1995.

11. NLCF. Korean carcass grading standard. Gunpo, Korea: National Livestock Cooperatives Federation; 2004. 17.

12. Sato S, Sako S, Maeda A. Social licking patterns in cattle (Bos taurus): Influence of environmental and social factors. Appl Anim Behav Sci 1991;32:3-12.

13.SAS. SAS user's guide: Statistics, 9.2 ed. Cary, NC: SAS Inst. Inc.; 2003.

14. Boe KE, Faerevik G. Grouping and social preferences in calves, heifers and cows. Appl Anim Behav Sci 2003;80:175-90.

15. Rind MI, Phillips CJC. The effects of group size on the ingestive and social behavior of grazing dairy cows. Anim Sci 1998; 68:589-96.

16.Li SG, Yang YX, Rhee YJ, et al. Growth, behavior, and carcass traits of fattening Hanwoo (Korean Native Cattle) steers managed in different group sizes. Asian-Australas J Anim Sci 2010; 23:952-9.

17. Berg RT, Butterfield RM. New concept of cattle growth. John Wiley and Sons. New York, USA: CRC Press; 1976. p. 35-83.

18. Kang SW, Oh YK, Kim KH, et al. Study on comparison of growth performance, feed efficiency and carcass characteristics for Holstein, Hanwoo and F1 (Holstein $+\times$ Hanwoo ${ }^{\Uparrow}$ ) steers. J Anim Sci Technol Korea 2005;47:243-52.

19. Lee SK, Panjono, Kang SM, et al. Effects of tethering and loose housing on the meat quality of Hanwoo bulls. Asian-Australas J Anim Sci 2008;21:1807-14.
20. KOSIS. Korean Statistical Information Service: Livestock grade determination statistics. Daejeon, Korea: Statistics Korea; 2016.

21.Lee SM, Jang JW. Effect of different stocking density on eating behavior of Hanwoo steers (Bos Taurus coreanae) during growing period. J Anim Sci Technol Korea 2011;53:489-96.

22. Kim HC, Jeon GJ, Na KJ, et al. A study on estimation of carcass traits in live Hanwoo by using the ultrasonic scanning method. Korea J Anim Sci 1995;37:336-40.

23. Hiroyuki K, Moriya NH, Korai T, et al. Nitric oxide suppresses preadipocyte differentiation in 3T3-L1 culture. Mol Cell Biochem 2007;300:61-7.

24. Houpt KA, Wollney G. Frequency of masturbation and time budgets of dairy bulls used for semen production. Appl Anim Behav Sci 1989;24:217-25.

25.KSAST. Korean cattle consulting guidelines. Seoul, Korea: J Anim Sci Technol Press; 2009. p. 223-62.

26. Kim NY, Kim SJ, Jang SY, et al. Behavioral characteristics of Hanwoo (Bos taurus coreanae) steers at different growth stages and seasons. Asian-Australas J Anim Sci 2017;30:1486-94.

27.Ishi K. Introduction of cattle behavior. Tokyo, Japan: Central Livestock Association Press; 1986. p. 18-56.

28. Kondo S, Kawakami N, Kohama H, Nishino S. Changes in activity, spatial pattern and social behavior in calves after grouping. Appl Anim Ethol 1984;11:217-28.

29.Zeeb K, Bock C, Heinzler B. Control of social stress by consideration of suitable space. In: Zayan R, Dantzer R, editors. Social stress in domestic animals. Dordrecth, Netherlands: Kluwer Academic Publishers; 1988. p. 275-81.

30. Jensen MB, Munksgaard L, Mogensen L, Korhn CC. Effect of housing in different social enviroments on open-field and social responses of female dairy calves. Acta Agric Scand Sect A-Anim Sci 1999;19:113-20. 